\title{
General Mutagenesis/Gene Expression Procedure for the Construction of Variant Immunoglobulin Domains in Escherichia coli
}

\section{Production of the Bence-Jones Protein $\mathrm{REI}_{\mathrm{v}}$ via Fusion to $\beta$-Lactamase} \author{
Harald Kolmar ${ }^{1,2} \uparrow$, Elisa Ferrando ${ }^{1, \dagger}+$ Frank Hennecke ${ }^{2}$, Jürgen Wippler $^{1,} \S$ and
Hans-Joachim Fritz \\ ${ }^{1}$ Max-Planck-Institut für Biochemie, Abteilung Zellbiologie \\ am Klopferspitz 18a, D-8033 Martinsried bei München, F.R.G. \\ ${ }^{2}$ (Corresponding address): Institut für Molekulare Genetik \\ Georg-August-Universität Göttingen \\ Grisebachstraße 8, D-3400 Göttingen, F.R.G.
}

\begin{abstract}
A novel mutagenesis/gene expression and protein purification scheme was established for ready construction and purification of variant immunoglobulin domains in Escherichia coli. This procedure, which has been applied to the production of the $V_{\kappa}$ domain of the Bence-Jones protein REI and structural variants of it, rests on the synthesis of chimeric proteins with $\beta$-lactamase as the amino-terminal fusion partner. The $\beta$-lactamase not only guides the fusion protein to the periplasmic space, but also allows affinity chromatography on phenylboronate-Sepharose as an efficient and general purification procedure, independent of hypervariable loop structure. The $\mathrm{REI}_{\mathrm{v}}$ protein was released from the purified fusion protein by site-specific proteolytic cleavage. After a second passage through the same affinity column, up to $2 \mathrm{mg}$ of pure $\mathrm{REI}_{\mathrm{v}}$ was obtained starting from one liter of bacterial liquid culture. A scheme of oligonucleotide-directed mutagenesis was introduced for replacement of DNA stretches encoding hypervariable loops. It exploits a colony color genetic screen and can be applied to any DNA sequence replacement. Mutations can be constructed by simple co-transformation with single-stranded template DNA and mutagenic oligonucleotide.
\end{abstract}

Keywords: affinity chromatography; immunoglobulin; $\beta$-lactamase; protein secretion; $\operatorname{IgA}$ protease

During recent years, a number of strategies have emerged for engineering antibodies and antibody fragments (for a review, see Winter \& Milstein, 1991). With the ease of manipulating antibody genes, e.g. for the construction of antibody fragments with catalytic activity (Baldwin \& Schultz, 1989), production of single-chain antibody fragments (Bird et al., 1988; Huston et al., 1988;

$\dagger$ Author to whom correspondence should be addressed, in Göttingen.

† Present address: Max-Planck-Institut für Biochemie, Abteilung Membranbiochemie, am Klopferspitz 18a, D-8033 Martinsried bei München, F.R.G.

$\S$ Present address: F. HOFFMANN-LA ROCHE LTD Pharma Division, Preclinical Research, CH-4002 Basle, Switzerland

Konstanzer Online-Publikations-System (KOPS) URN: http://nbn-resolving.de/urn:nbn:de:bsz:352-220652
Glockshuber et al., 1990) or generation of combinatorial libraries of the immunoglobulin repertoire via PCR\| cloning (Ward et al., 1989; Huse et al., 1989), Escherichia coli became an attractive expression host for the production of variant immunoglobulins.

For production of engineered antibody fragments in $E$. coli, numerous methods have been devised, which differ mainly in the cellular locale of the protein produced, i.e. cytoplasm or periplasmic space (for a review, see Wetzel, 1988). Generally, cytoplasmic localization of newly synthesized

|| Abbreviations used: $\mathbf{P C R}$, polymerase chain reaction; $\mathrm{CDR}$, complementarity-determining region; $b \mathrm{p}$, basepair(s); IPTG, isopropyl- $\beta$-D-thiogalactopyranoside; X-P, 5-bromo-4-chloro-3-indolyl-phosphate. 
immunoglobulin Fab or Fv fragments in large quantities was accompanied by deposition of the proteins within the cell as insoluble inclusion bodies (Cabilly et al., 1984; Boss et al., 1984; Field et al., 1990). However, reconstitution often led to only a small fraction of correctly folded protein. Alternative strategies have been established, that mimic the folding and assembly pathway of antibodies in eukaryotic cells by simultaneous expression of both immunoglobulin chains in the same $E$. coli cell and concomitant secretion into the periplasmic space where protein folding, disulfide bond formation as well as heterodimer association was shown to occur correctly (Better et al., 1988; Skerra \& Plückthun, 1988).

With the ease of introducing site-specitic mutations within genes cloned in $E$. coli (for a review, see Kramer \& Fritz, 1990), generation and analysis of a broad immunoglobulin mutant spec. trum is a powerful tool to gain closer insight into the influence of certain residues on antigen binding (Roberts et al., 1987), protein stability (Glockshuber et al., 1990) and loop conformation (Chothia et al.. 1989). We are particularly interested in elucidating the structural role of key conserved residues within immunoglobulin complementarity determining regions (CDRs). Comparative studies of known antibody structures indicate that these residues mainly determine hypervariable loop conformations (Chothia \& Lesk, 1987; Chothia et al., 1989). For example, a particular CDRl loop conformation was deduced to be due to interaction of $V_{\kappa}$ L.1 loop residue 29 with framework residues $2,25,33$ and 71 (Chothia \& Iesk, 1987; Chothia et al., 1989). We have embarked on an attempt to understand the nature of these interactions and their influence on loop conformation and protein stability by systematically varying such key conserved residues by means of directed mutagenesis. As a start, we decided to produce a set of variants of the $V_{\kappa}$ domain of the Bence-Jones protein REI (REI Palm, 1970; Epp et al., 1975) carrying different residues at position 29 of CDR 1 .

For the facile generation and purification of these $\mathrm{REI}_{\mathrm{v}}$-derived variant proteins the mutagenesis/ expression vector pHKREI has been constructed (Fig. 1(a)). It contains a tripartite fusion gene consisting of the complete coding sequence for pBR322-derived $\beta$-lactamase (Sutcliffe, 1978), a synthetic gene encoding the variable domain $\mathrm{REI}_{\mathrm{v}}$ of the Bence-Jones protein REI (rei; Fig. 1(b)) and the coding region for mature alkaline phosphatase from $E$. coli (Chang et al., 1986). All three genes are fused in frame. Presence of the $\beta$-lactamase signal sequence directs the fusion protein, synthesized under control of the lac promoter/operator region, to the periplasmic space. 'The $\mathrm{REI}_{\mathrm{v}}$ coding region is preceded by a $30 \mathrm{bp}$ linker region coding for the recognition sequence for $\operatorname{IgA}$ protease from Neisseria gonorrhoeae (Pohlner et al., 1987). The phoA gene segment lacks its promoter, signal sequence-encoding region and the first five codons of its coding sequence. An amber stop codon has been introduced between the rei and the pho $A$ gene leading to production of a tripartite $\beta$-lactamase- $\mathrm{REI}_{\mathrm{v}}$-alkaline phosphatase fusion protein in an amber suppressor host. Expression in a non-suppressor host yields only the bipartite $\beta$-lactamase- $\mathrm{REI}_{\mathbf{v}}$ fusion protein.

Upon induction with IPTG, an additional protein of expected apparent molecular weight ( $\beta$-lactamase-REI fusion protein: $M_{\mathrm{r}} 41,800$ ) was found in the periplasmic extract of a non-suppressor $E$. coli K-12 host (WK-6) carrying pHKREI (Fig. 2(a)). In immunoblots, this protein was recognized by an anti- $\beta$-lactamase serum (data not shown). Cells harboring pHKREI were able to grow, even without addition of IPTG, on agar plates containing ampicillin $(100 \mu \mathrm{g} / \mathrm{ml})$. This indicates that $\beta$-lacta mase is enzymatically active when fused to the $\mathrm{REI}_{\mathrm{v}}$ domain and that the fusion protein is secreted into the periplasmic space, which is the usual cellular locale of pBR322-encoded $\beta$-lactamase (Koshland \& Botstein, 1980).

The $\beta$-lactamase-REI fusion protein was puritied from periplasmic extracts exploiting the affinity of the $\beta$-lactamase moiety to boric acid and phenyliboronic acid (Kiener \& Waley 1978; Beesley et al. 1983). The fusion protein could be purified to near homogeneity (Fig. 2(b)) using a phenylboronateSepharose affinity column with hydrophobic spacer arms (Cartwright \& Waley, 1984). Tsing E. coli B strain BL21 (Studier \& Moffat. 1986), usually $6 \mathrm{mg}$ of fusion protein per liter of liquid culture have been obtained. Amounts of fusion protein found in the periplasmic space were lower for WK-6 than for BL21. A possible explanation is the absence of both the intracellularly located La protease (Waxman \& Goldberg, 1982) and the outer membrane protease OmpT (Baneyx \& Georgiou, 1990) from $E$. coli B cells. With a slightly modified purification pro cedure (Hennecke ot al., 1991) a fusion protein with $\beta$-lactamase as amino-terminal and a single-chain Fv fragment (Clackson et al. 1991) of antibody. NQ10.12.5. (Berek ot al. 1985) as carboxy-terminal fusion partner could be highly enriched. which exhibited binding to the $\mathrm{NQ10.12.5}$ hapten 2-phenyloxazol-5-one (data not shown)

Release of the $\mathrm{REI}_{v}$ moiety from the purified fusion protein was achieved by site-specific proteolytic cleavage of the Pro-Thr peptidic bond within the sequence Pro-Pro-Thr-Pro. the recognition site of IgA protease from $N$. gonorrhoeae (Pohlner et al. 1987). This sequence had been introduced into the $\beta$-lactamase- $\mathrm{REI}_{\mathrm{v}}$ fusion protein directly preceding the REI, amino terminus (see Fig. I(a)). IgA protease cleavage was performed with a molar ratio of substrate to enzyme of $150: 1$. After 24 homrs of incubation at $37^{\circ} \mathrm{C}$ cleavage was almost complete (Fig. 3). In contrast, the site-specific protease factor Xa (Nagai \& Thøgersen, 1984) failed to cleave a $\beta$ lactamase- $\mathrm{REI}_{v}$ fusion protein containing, instead the recognition sequence Ile-Glu-Gly-Arg. This may be due to different demands of the two proteolytic enzymes with respect to arcessibility of their respective cleavage site 
TGG GTC GAC CCA GCT CCT AGG CCT CCA ACG CCT GAT ACC CAG CT G GGT CGA GGA TCC GGA GGT T GC GGA CTA Trp Val Asp Pro Ala Pro Arg Pro Pro 4 Thr Pro Asp

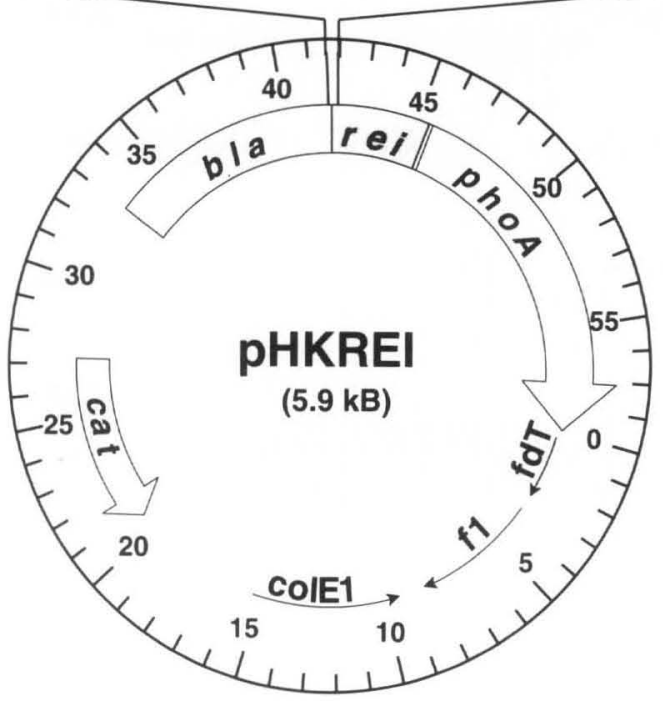

(a)

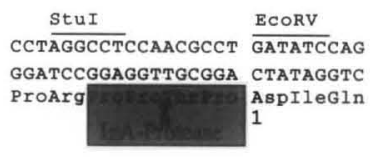

10 30

50

ATGACT CAGTCTCCGAGCAGTCTGTCAGCGAGCGTTGGTGACCGTGTTACTATCACTTGC TACTGA GTCAGAGGCTCGTCAGACAGTCGCTCGCAACCACTGGCACAATGATAGTGAACG MetThrGlnSerProSerSerLeuSerAlaSerVa1GlyAspargValThrIleThrCys 10

70

90 Asp 718. SmaI CAGGCT MGCCAGGACATCATCAAATACCTGAACTGGTACCAGCAGACCCCGGTAAAGCT CTCCGACCGGTCCTOTAGTAGTTATGFACTTGACCATGGTCGTCTGGGCCCATTTCGA GInAla SerGInAspIleI1eLYsTyxLeuAsnTrPTyrGInGInThrPROGIYLYsAla CDR 130

CCGAAA TTGCTGATCTACGAAGCATCTAACCTGCAGGCTGGTGTTCCCTCGAGGTTCTCT GGCTTT GACGACTAGATGCTTCGTAGATTGGACGTCCGACCACAAGGGAGCTCCAAGAGA ProLysLeuLeuI leTyroluAlaserAsnLeuGInAlaGlyValproSerArgPheSer $50 \mathrm{CDR} 2$ 60

190 210 230

GTTCTGGTTCTGGTACTGACTACACTTTCACTATCAGCTCACTGCAACCGGAAGACATC CCAAGACCAAGACCATGACT GATGTGAAAGTGATAGTCGAGTGACGTTGGCCTTCTGTAG GlySerGlySerGlyThrAspTyrThrPheThrIleSerSerLeuGlnProGluAspIle 70

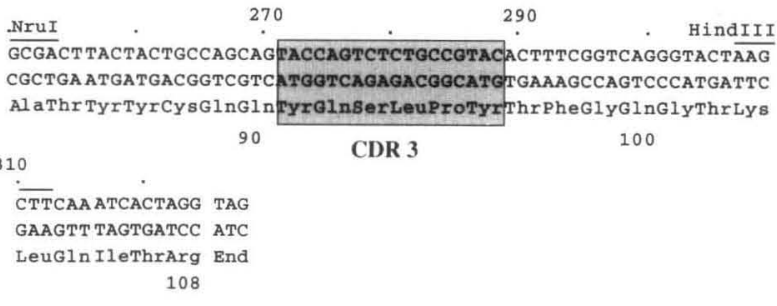

(b)

Figure 1. Physical and genetic map of expression vector $\mathrm{pHKREI}$ and nucleotide sequence of the synthetic rei gene. (a) Expression vector $\mathrm{pHKREI}$, which has been constructed by several rounds of cloning and oligonucleotide directed mutagenesis using standard techniques (Maniatis et al., 1982; Kunkel et al., 1987; Stanssens et al., 1989 ). It contains an fl phage-derived origin of replication
The $\mathrm{REI}_{\mathrm{v}}$ protein released by IgA protease contains two additional amino-terminal residues (Thr-Pro) and is therefore designated REI TP. The cleavage mixture, containing $\operatorname{IgA}$ protease, $\mathrm{REI}_{\mathrm{v}} \mathrm{TP}, \quad \beta$-lactamase and uncleaved $\beta$-lactamase- $\mathrm{REI}_{\mathrm{v}}$ fusion protein, was applied directly to the phenylboronate-Sepharose affinity column. The liberated REI TP moiety was found exclusively in the flow-through, while the $\beta$-lactamase-REI fusion protein and the $\beta$-lactamase moiety of the fusion were retained (Fig. 3). Fortuitously, IgA protease also binds to the phenylboronate-Sepharose affinity column. After passage through the second affinity column, $2 \mathrm{mg}$ of pure REI $\mathrm{TP}$ was obtained starting from one liter of bacterial liquid culture.

In gel filtration experiments using a Sephadex G75 column, $\mathrm{REI}_{\mathrm{v}}$ protein isolated from genuine myeloma Bence-Jones protein REI exhibits an apparent $M_{\mathrm{r}}$ of about 24,000 indicating dimerization as expected from the crystal structure (Epp et al., 1975). The same apparent molecular weight was found for REI TP isolated as described above (data not shown). Since it is reasonable to assume dimerization to require native structure of the monomer, we take this finding as an indication of correct folding of $\mathrm{REI}_{\mathrm{v}} \mathrm{TP}$. Furthermore, REI ${ }_{\mathrm{v}} \mathrm{TP}$ and genuine $\mathrm{REI}_{\mathrm{v}}$ exhibited similar transition curves upon reversible urea denaturation indicating a conformational stability of both proteins of the order of $21 \mathrm{~kJ} / \mathrm{mol}$ (data not shown).

In phasmid vector $\mathrm{pHKREI}$ the $\beta$-lactamase-rei fusion gene is separated from the $E$. coli gene phoA, encoding alkaline phosphatase by an amber stop codon. In the amber suppressor strain BMH71-18 (Kramer et al., 1984) a tripartite fusion protein consisting of $\beta$-lactamase, $\mathrm{REI}_{\mathrm{v}}$ and alkaline phos-

(f1), a ColE1 plasmid replication origin derived from pBR322 (colE1), a gene encoding chloramphenicol acetyl transferase (cat) and a tripartite fusion gene encoding $\beta$ lactamase (bla; ranging from nucleotide pairs 2546 to 1689 according to GenEMBL accession no. VB0040), $\mathrm{REI}_{\mathrm{v}}(\mathrm{rei}$; (b)) and alkaline phosphatase ( $p h o A$; ranging from nucleotide pairs 361 to 1695 according to GenEMBL accession no. X04586). The bla and rei genes are connected by a synthetic $30 \mathrm{bp}$ adaptor encoding the recognition sequence of IgA protease from $N$. gonorrhoeae (Pohlner et al., 1987). The recognition sequence for $\operatorname{IgA}$ protease is shaded, the point of cleavage is indicated by an arrow. The fusion gene is expressed under lac promoter control (Messing \& Vieira, 1982). (b) Nucleotide sequence of the synthetic rei gene and corresponding $\mathrm{REI}_{\mathrm{v}}$ protein sequence. The DNA sequence was deduced from the protein sequence (Palm \& Hilschmann, 1973). The redundance of the genetic code was exploited to introduce a number of restriction sites. Otherwise, the most frequently occurring $E$. coli codons were chosen. The gene was assembled in phasmid vector pMa5-8 (Stanssens et al. 1989) by stepwise cloning of complementary oligonucleotide pairs. Relevant restriction enzyme sites are indicated. The DNA stretches encoding the IgA protease recognition sequence and the hypervariable loop regions are displayed in shaded boxes. 


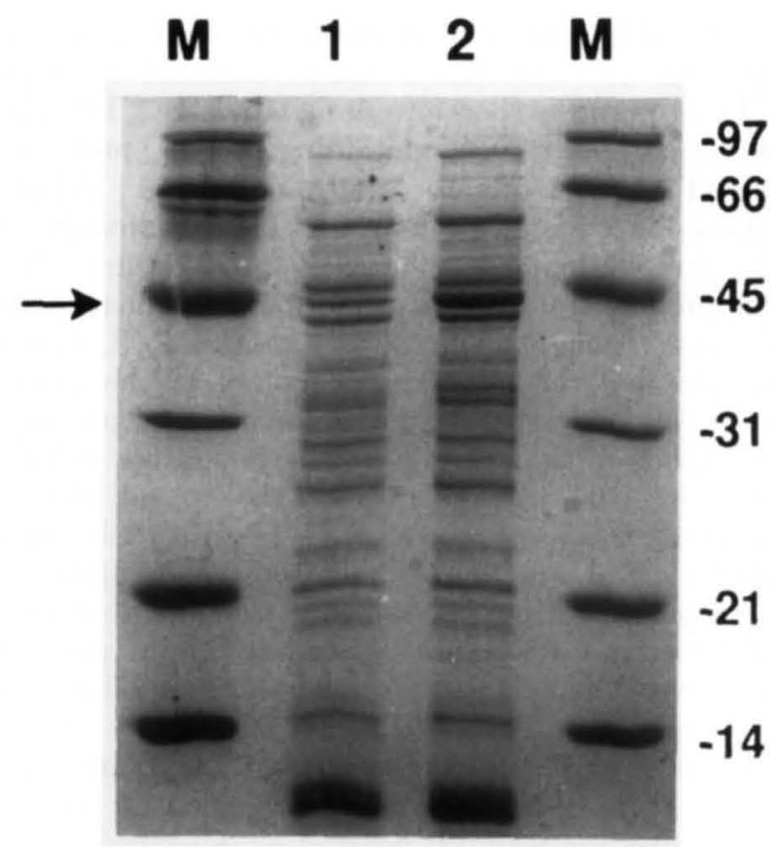

(a)

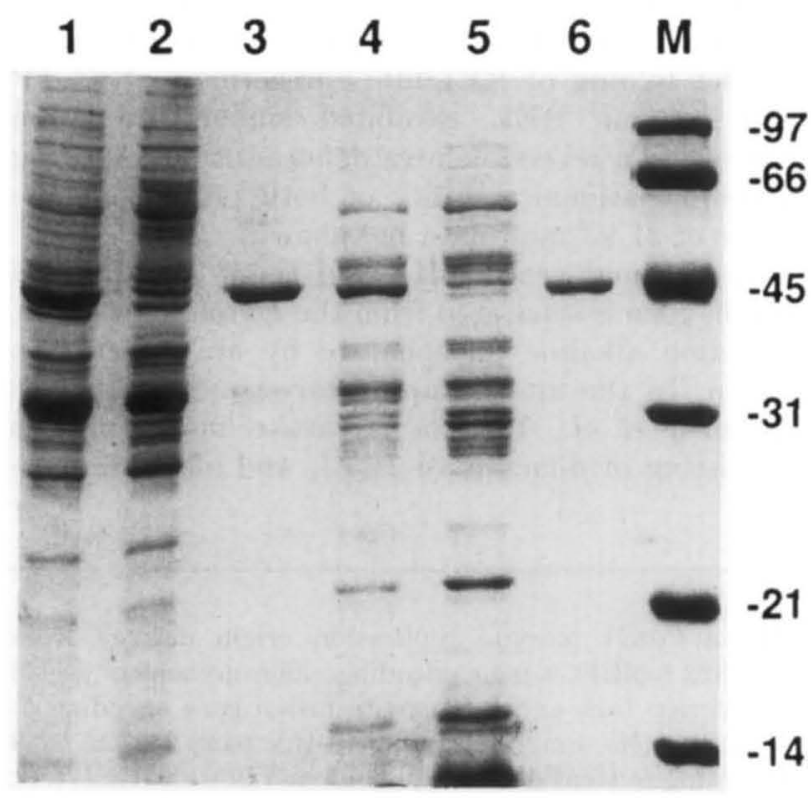

(b)

Figure 2. (a) Production of $\beta$-lactamase-REI $\mathrm{I}_{v}$ fusion protein analyzed by SDS/polyacrylamide gel electrophoresis $(15 \%$ gel; Coomassie staining). Lane 1, fraction of periplasmic proteins of $E$. coli WK-6 harboring phasmid pHKREI; lane 2, fraction of periplasmic proteins of an IPTG-induced E. coli WK-6 harboring pHKREI. The position of the $\beta$-lactamase-REI fusion $_{v}$ protein is indicated by an arrow. M, molecular mass markers with masses indicated $\left(\mathrm{Da} \times 10^{-3}\right)$. E. coli WK-6 $\left[\Delta\left(\right.\right.$ lac-pro), galE, rpsL $; F^{\prime} l a c I^{q} Z \Delta M 15$, proA $\left.^{+} B^{+}\right]$(source W. Kramer) harboring pHKREI was grown overnight in 11 of rich medium at $30^{\circ} \mathrm{C}$ with chloramphenicol $(25 \mathrm{mg} / \mathrm{l})$ and IPTG (1 mM) added. Periplasmic extracts were prepared by an adaptation of the procedure described by Neu \& Heppel (1965). Cells were collected by centrifugation and resuspended in $200 \mathrm{ml}$ of $20 \%(\mathrm{w} / \mathrm{v})$ sucrose, 100 mм-EDTA, 200 mм-Tris $\cdot \mathrm{HCl}$ ( $\mathrm{pH} \mathrm{9.0)}$ ). The suspension was gently stirred for $30 \mathrm{~min}$. Cells were pelleted and shocked by resuspending in $200 \mathrm{ml}$ of

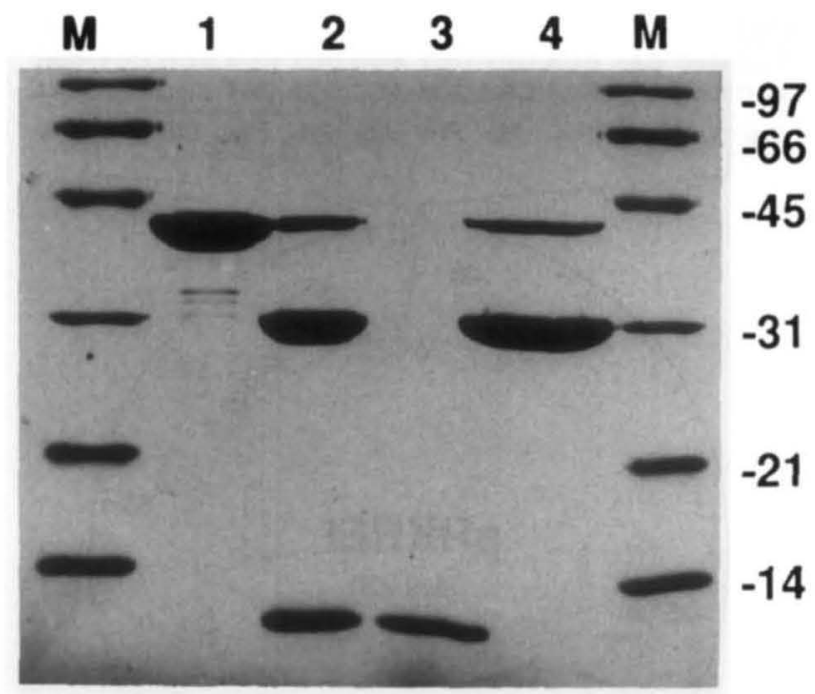

Figure 3. Cleavage of bipartite $\beta$-lactamase-REI fusion protein and affinity purification of $\mathrm{REI}_{\mathrm{v}} \mathrm{TP}$. Lane 1, $\beta$-lactamase- $\mathrm{REI}_{\mathrm{v}}$ fusion protein. affinity-purified as deseribed for Fig. 2(b); lane 2, after IgA protease cleavage; lane 3 . flow-through of phenylboronate-Sepharose affinity column: lane 4 . after elution with buffer $B$ (see the legend to Fig. 2(b)): M. molecular mass markers with masses indicated $\left(\mathrm{Da} \times 10^{-3}\right)$. IgA protease cleavage was performed with a molar ratio of enzyme to substrate of $1: 150$ in $50 \mathrm{~mm}$-ammonium acetate $(\mathrm{pH} 7.0)$ at $37^{\circ}$ (' for $24 \mathrm{~h}$. The sample was reapplied to the same affinity column used for the purification of the fusion protein (see the legend to Fig. 2(b)), pre-equilibrated with $50 \mathrm{~mm}$-ammonium acetate $(\mathrm{pH} 70)$. The flow-through containing unbound $\mathrm{REI}_{\mathrm{v}} \mathrm{TP}$ protein $\left(M_{\mathrm{r}} 12.100\right)$ was collected. Bound material was eluted with buffer B (see the legend to Fig. 2(b)).

$10 \mathrm{~mm}$-Tris. $\mathrm{HCl}(\mathrm{pH} \mathrm{8.8})$. They were stirred again for $30 \mathrm{~min}$ at $4^{\circ} \mathrm{C}$ and recentrifuged. Periplasmic protein was precipitated from the supernatant by addition of ammonium sulfate to $90 \%$ saturation. After centrifugation, the protein precipitate was dissolved in $20 \mathrm{ml}$ of $0.5 \mathrm{M}-\mathrm{NaCl}$. 20mm-triethanolamine- $\mathrm{HCl}(\mathrm{pH} 7 \cdot 0)$. (b) Analysis of various stages in the purification of $\beta$-lactamase- $R E I_{v}$ fusion protein (SDS $/ 15 \%$ polyacrylamide gel; Coomassie staining). Lanes 1 and 4 , total periplasmic extract of induced $E$. coli BL2L (lane 1) or WK-6 (lane 4), respectively, harboring pHKREI; lanes 2 and 5 . fraction of unbound proteins after passage through phenylboronateSepharose affinity column; lanes 3 and 6 . affinity-purified $\beta$-lactamase-REI fusion protein after column elution with $0.5 \mathrm{~m}$-sodium borate, $0.5 \mathrm{~m}-\mathrm{NaCl}, \mathrm{pH} \mathrm{7.0;} \mathrm{M}$, molecular mass markers with masses indicated $\left(\mathrm{Da} \times 10^{-3}\right)$. Affinity chromatography was performed on phenylboronate-Sepharose with a hydrophobic spacer arm (Cartwright \& Waley, 1984). The column (10 ml bed volume) was equilibrated with buffer A (20 mu-triethanolamine- $\mathrm{HCl}, 0.5 \mathrm{n}-\mathrm{NaCl}, \mathrm{pH} 7 \cdot 0$ ). The sample was loaded at $4^{\circ} \mathrm{C}$ with a flow rate of $40 \mathrm{ml} / \mathrm{h}$ and washed with 5 column volumes of buffer $A$. Fractions eluted with buffer B (0.5 M-sodium borate, $0.5 \mathrm{~m}-\mathrm{Na}(\mathrm{l}$, $\mathrm{pH} 7.0$ ) were combined and dialyzed against $50 \mathrm{~mm}$-ammonium acetate $(\mathrm{pH} 7 \cdot 0)$ at $4^{\circ} \mathrm{C}$. 


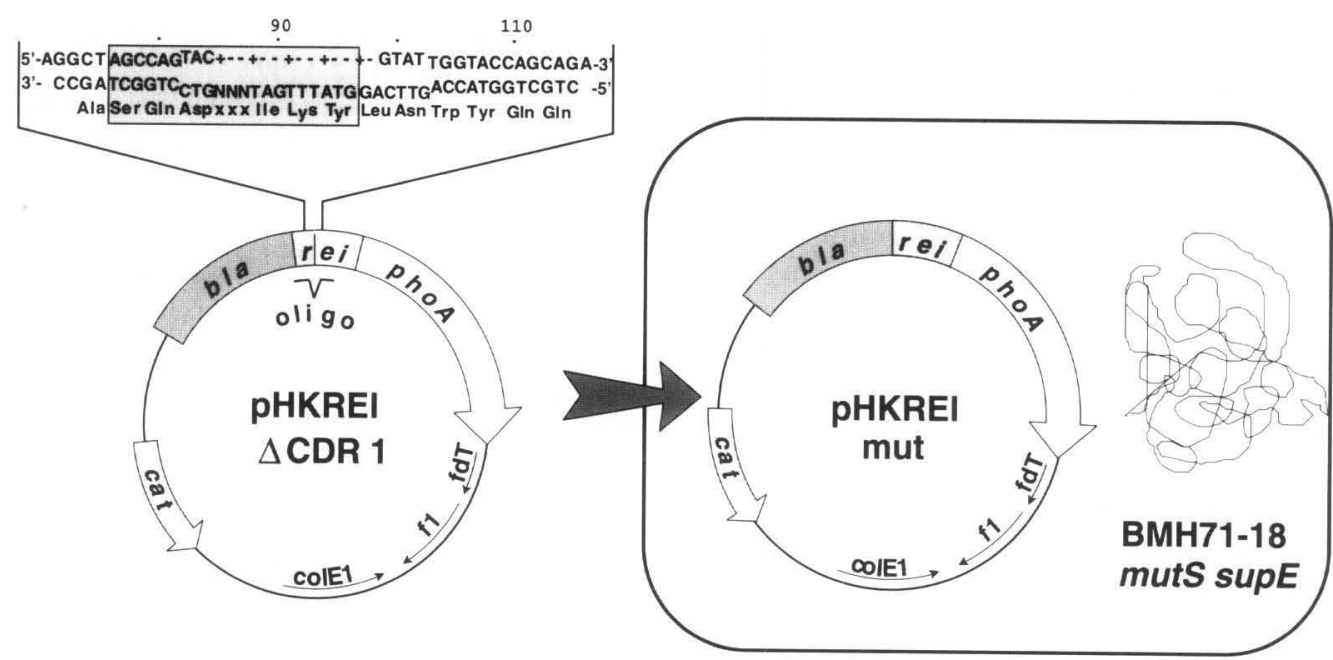

Figure 4. A diagram showing the oligonucleotide-directed mutagenesis procedure employed for the construction of $\mathrm{REI}_{\mathrm{v}}$ derivatives with codon substitutions at position 29 of CDRl. The situation at the DNA stretch of the rei gene encompassing the CDRl coding region is shown above the phasmid. The nucleotide sequence of the lower strand corresponds to the mutagenic oligonucleotide. Likewise, in pHKREI- $\triangle \mathrm{CDR} 2$ and pHKREI- $\triangle \mathrm{CDR} 3$ the CDR2 or CDR3-encoding regions, respectively, were removed by directed mutagenesis using the mutagenic oligonucleotides MUACDR2 (5'-pGGAACACCATACGTAGATCAG-3') or MUACDR3 (5'-pCCGAAAGTATACGTACTGCTG-3'). For the generation of variant rei genes via transformation of a mismatch repair-deficient host strain with single-stranded DNA and mutagenic oligonucleotide, $10 \mathrm{pmol}$ of the respective phosphorylated oligonucleotide was hybridized to $100 \mathrm{ng}$ of single-stranded DNA of pHKREI- $\triangle$ CDRl prepared from $E$. coli strain BMH71-18. Hybridization conditions were $150 \mathrm{mM}$-sodium chloride, $15 \mathrm{~mm}$-sodium eitrate in a final volume of $20 \mu \mathrm{l}$. After incubation at $100^{\circ} \mathrm{C}$ for $2 \mathrm{~min}$ and at $65^{\circ} \mathrm{C}$ for $5 \mathrm{~min}$, the mixture was used to transform $E$. coli strain BMH71-18/mutS (Kramer et al., 1984). The transformation mixture was plated onto indicator plates containing DIFCO Antibiotic Medium 3 (17.5 g/l), Bacto-Agar ( $15 \mathrm{~g} / \mathrm{l})$, chloramphenicol $(25 \mathrm{mg} / \mathrm{l})$, IPTG $(238 \mathrm{mg} / \mathrm{l})$ and X-P disodium salt $(60 \mathrm{mg} / \mathrm{l})$. To allow complete marker segregation, phasmid DNA was isolated from blue colonies and used for retransformation of E. coli BMH71-18.

phatase is synthesized and secreted. This results in a blue colony phenotype on indicator plates containing the chromogenic substrate 5-bromo-4chloro-3-indolyl-phosphate (X-P; Sarthy et al., 1981). Alkaline phosphatase was shown to be enzymatically active only when secreted into the periplasmic space (Michaelis et al., 1983). For that reason measurement of alkaline phosphatase activity provides a simple and quantitative means to determine the efficiency of protein synthesis plus secretion (Hoffman \& Wright, 1985; Manoil \& Beckwith, 1986).

To facilitate oligonucleotide-directed mutagenesis within the CDR-encoding DNA regions of the rei gene, three derivatives of vector $\mathrm{pHKREI}$ were constructed, each containing a deletion within the DNA segment encoding CDR1, CDR2, or CDR3, respectively (Fig. 4). In addition to removing several codons, each deletion causes a frameshift such that formation of the tripartite fusion protein is precluded even in the amber suppressor host. A structurally altered CDR can now be introduced with restoration of the reading frame simply by insertion mutagenesis with a synthetic oligonucleotide. Thus, successful mutation constructs are scored as blue colonies after transformation of a host strain carrying an amber suppressor. Here we demonstrate the procedure as used for substitutions of CDR1 residue Ile29 (Fig. 4). With the mutagenesis protocol described by Kunkel et al. (1987) routinely $20 \%$ blue colonies were found on indicator plates containing X-P. Alternatively, mutant genes were generated by plain cotransfection of the DNA mismatch repair deficient strain BMH71-18/mutS (Kramer et al., 1984) with the pHKREI- $\triangle$ CDR1 single-stranded DNA and the mutagenic oligonucleotide (Fig. 4). With this procedure, a further simplification of the mix-heat-transfect protocol (Fritz et al., 1988), around 1 to $2 \%$ blue colonies were obtained. Reintroduction of the CDR1encoding DNA stretch together with the desired substitution of codon 29 was confirmed in each mutagenesis experiment by nucleotide sequence analysis (Ansorge et al., 1987). A number of $\mathrm{REI}_{\mathrm{v}}$ variants, containing e.g. Leu, Val, Ala, Ser or His at the CDR1 position 29 have been isolated and purified to homogeneity using the purification scheme described above. A detailed analysis of the conformational stabilities of these $\mathrm{REI}_{\mathrm{v}}$ derivatives will be published elsewhere.

In summary, a novel expression/purification scheme for the production of immunoglobulin light chain variable domains and single-chain $\mathrm{Fv}$ fragments in $E$. coli was established, which rests on fusion to $\beta$-lactamase. We exploited the fact that $E$. coli $\beta$-lactamase is a periplasmic enzyme to guide the bipartite fusion protein consisting of $\beta$-lactamase and the immunoglobulin variable domain $\mathrm{REI}_{\mathrm{v}}$ and the tripartite fusion protein consisting of $\beta$-lactamase, $\mathrm{REI}_{\mathrm{v}}$ and alkaline phosphatase into the periplasmic space. In a number of instances, the secretion of heterologous proteins into the periplasmic space of $E$. coli has proven to be helpful for correct protein folding (Michaelis et al., 1983; 
Hsiung et al., 1986). This is particularly important for cases like immunoglobulins, in which disulfide bonds must be formed, a process requiring an oxidizing environment as provided by the periplasmic space (Skerra \& Plückthun, 1988).

For the purification of immunoglobulins, their respective hapten-binding properties can be exploited in affinity chromatography schemes (Skerra \& Plückthun, 1988; Riechmann et al., 1988). Obviously, for the isolation of immunoglobulins modified in such a way, that their hapten binding properties are changed (e.g. by mutations in their hypervariable regions), a general purification procedure must be based on principles other than hapten binding. We have solved this problem by employing $\beta$-lactamase as a specific affinity handle. Similarly, an oligohistidine extension of the immunoglobulin has been used (Skerra et al., 1991). After purification by chromatography on phenylboronate-Sepharose (Cartwright \& Waley, 1984). the $\beta$-lactamase moiety can be removed by sitespecific enzymatic proteolysis and subsequent affinity chromatography using the same purification scheme.

For the generation of specific CDR modifications, a mutagenesis and screening procedure was established, in which successful mutation constructions are scored as blue colonies. Starting from three, or for single-chain $F_{v}$ fragments six, different constructions of the immunoglobulin gene carrying deletions in the respective CDR-encoding DNA stretches, the desired mutation(s) can be introduced simply by insertion mutagenesis with a synthetic oligonucleotide; the latter brings in the sequence of the desired loop replacement. By means of an alternating phenotypic detection (colorless/blue colony phenotype) of clones carrying the desired mutation. multiple replacements can be performed in consecutive rounds of oligonucleotide-directed mutagenesis (J. Pschorr \& G. Kleemann, unpublished results). Since the genetic detection scheme and the procedures of protein production/purification introduced here are of a general nature, we propose that they will be applicable to the generation of framework mutants and also to the engineering of proteins other than immunoglobulins.

The authors express their thanks to Dr J. Pohlner (Max-Planck-Institut für Biologie, Tübingen) for the gift of IgA protease, and to Dr O. Epp (Max-Planck Institut für Biochemie, Martinsried) for helpful advice and comments. This work was supported by a grant of the German Bundesminister für Forschung und Technologie through Forschungsschwerpunkt "Grundlagen der Bioprozeßtechnik". H.K. is recipient of a "Kekulé" fellowship from Fonds der Chemischen Industrie.

\section{References}

Ansorge, W., Sproat, B., Stegemann, J., Schwager, C. \& Zenke, M. (1987). Automated DNA sequencing: ultrasensitive detection of fluorescent bands during electrophoresis. Nucl. Acids Res. 15, 4593-4602.

Baldwin. E. \& Schultz, P. G. (1989). Generation of a catalytic antibody by site-directed mutagenesis. Science, 245, 1104-1107.

Baneyx, F. \& Georgiou, G. (1990). In vivo degradation of secreted fusion proteins by the Escherichia coli outer membrane protease OmpT. J. Bacteriol. 172. 491-494.

Beesley, T. Gascoyne, N., Knott-Hunziker. $\quad V$. Petursson, S. Waley, S. G., Jaurin, B. \& Grundström, T. (1983). The inhibition of class ( $\beta$-lactamases by boronic acids. Biochem. J. 209. 229-233.

Berek, C. Griffiths, G. M. \& Milstein, (. (1985). Molerular events during maturation of the immune response to oxazolone. Nature (London), 316. 412-418.

Better, M., (hang, C. P.. Robinson, R. R. \& Horwitz. D. H. (1988). Escherichia coli secretion of an active chimeric antibody fragment. Science, 240. 1041-1043.

Bird, R. E. Hardman. K. D., Jacobson, J. W.. Johnson. S., Kaufman, B. M., Lee, S.-M., Lee, T., Pope, S. H. Riordan, G. S. \& Whitlow, M. (1988). Single-chain antigen-binding proteins. Science, 242, 423-426.

Boss, M. A.. Kenten, J. H.. Wood, C. R. \& Emtage, J. s. (1984). Assembly of functional antibodies from immunoglobulin heavy and light chains synthesised in E. coli. Nucl. Acids Res. 12. 3791 3806.

Cabilly, S., Riggs, A. 1). Pande, H., Shively, .J. E. Holmes, W. E. Rey, M., Perry, I. J.. Wetzel, R. \& Heyneker. H. L. (1984). Generation of antibody activity from immunoglobulin polypeptide chains produced in Escherichia coli. Proc. Nat. Acad. sci. I.S.A. 81. 3273-3277.

Cartwright, S. J. \& Waley, S. G. (1984). Purification of $\beta$-lactamases by affinity chromatography on phenyboronic acid-agarose. Biochem. I. 221, 505-512

Chang. C. N., Kuang, W.-J. \& Chen. E. Y. (1986). Nucleotide sequence of the alkaline phosphatase gene of Escherichia coli. Gene, 44, 121-125.

Chothia. (.\& Lesk. A. M. (1987). Canonical structures for the hypervariable regions of immunoglobulins. J. Mol. Biol. 196, 901-917

Chothia ( .. Lesk, A. M., Tramontano, A., Levitt, M. Smith-Gill, S. J.. Air, G. Sheriff, S.. Padlan. E. A.. Davies. D.. Tulip, W. R. Colman, P. M.. Spinelli, \&. Alzari, P. M. \& Poljak, R. .J. (1989). Conformations of immunoglobulin hypervariable regions. Nalure (London), 342. 877-883.

Clackson. T.. Hoogenboom. H. R.. Griffiths. A. I), \& Winter, G. (1991). Making antibody fragments using phage display libraries. Nature" (London). 352. 624-628.

Epp. O., Lattmann, E. E., Schiffer. V., Huber. R. \& Palm, W. (1975). The molecular structure of a dimer composed of the variable portions of the Bence-Jones protein RET refined at 20 -A resolution. Biochemistry. 14. 4943-4952.

Field. H., Yarranton ( $x$, 'T. \& Rees, A. R. (1990). Expression of mouse immunoglobulin light and heavy chain variable regions in Escherichia coli and reconstitution of antigen-binding activity. Protein Eng. 3, 641-647.

Fritz, H.-J., Hohlmaier, J.. Kramer, W.. ohmayer. A. \& Wippler. J. (1988). Oligonucleotide-directed construction of mutations: a gapped duplex DNA procedure without enzymatic reaction in nitro. Nucl. Acids Res. 16, 6987-6999.

Glockshuber, R., Malia. M.. Pfitzinger. I.\& Plïrkthun. A (1990). A comparison of strategies to stabilize immunoglobulin Fv-fragments. Biochemistry, 29. $1362-1367$ 
Hennecke, F., Kolmar, H., Bründl, K. \& Fritz, H.-J. (1991). The vsr gene product of $E$. coli $\mathrm{K}-12$ is a strand- and sequence-specific DNA mismatch endonuclease. Nature (London), 353, 776-778.

Hoffman, C. S. \& Wright, A. (1985). Fusions of secreted proteins to alkaline phosphatase: an approach for studying protein secretion. Proc. Nat. Acad. Sei., U.S.A. 82, 5107-5111

Hsiung, H. M.. Mayne, N. G. \& Becker, G. W. (1986). High-level expression, efficient secretion and folding of human growth hormone in Escherichia coli. Biotechnology, 4, 991-995.

Huse, W. D., Sastry. L., Iverson, S. A., Kang. A. S. Alting-Mees, M., Burton, D. R., Benkovic, S. J. \& Lerner, R. A. (1989). Generation of a large combinatorial library of the immunoglobulin repertoire in phage lambda. Science, 246, 1275-1281.

Huston, J. S., Levinson, D., Mudgett-Hunter, M., Tai, M.S., Novotny. J., Margolies, M. N., Ridge, R. J., Bruccoleri, R. E., Haber, E., Crea, R. \& Oppermann, H. (1988). Protein engineering of antibody binding sites: Recovery of specific activity in an anti-digoxin single-chain $\mathrm{Fv}_{\mathrm{v}}$ analogue produced in Escherichia coli. Proc. Nat. Acad. Sci., U.S.A. 85, 5879-5883.

Kiener, P. A. \& Waley, S. G. (1978). Reversible inhibitors of penicillinases. Biochem. J. 169, 197-204

Koshland, D. \& Botstein D. (1980). Secretion of betalactamase requires the carboxy end of the protein. Cell. 20. 749-760.

Kramer, B.. Kramer. W. \& Fritz, H.-J. (1984). Different base/base mismatches are repaired with different efficiencies by the methyl-directed DNA mismatchrepair system of Escherichia coli. Cell, 38, 879-887.

Kramer, W. \& Fritz, H.-J. (1990). Oligonucleotidedirected mutagenesis. In Modern Methods in Protein and Nucleic Acid Analysis (Tschesche, H., ed.), pp 19-35. Walter de Gruyter, Berlin and New York

Kunkel. T. A., Roberts, J. D. \& Zakour, R. A. (1987). Rapid and efficient site-specific mutagenesis without phenotypic selection. Methods Enzymol. 154 , $367-382$.

Maniatis. T.. Fritsch, E. F. \& Sambrook, J. (1982). Molecular Cloning: A Laboratory Manual, Cold Spring Harbor Laboratory Press, Cold Spring Harbor, NY

Manoil. C. \& Beckwith, J. (1986). A genetic approach to analyzing membrane protein topology. Science, 233. $1403-1408$

Messing, J. \& Vieira, J. (1982). A new pair of M13 vectors for selecting either DNA strand of double-digest restriction fragments. Gene, 19, 269-276.

Michaelis, S.. Inouye, H., Oliver, D. \& Beckwith, J. (1983). Mutations that alter the signal sequence of alkaline phosphatase in Escherichia coli. J. Bacteriol. 154, $366-374$

Nagai, K. \& Thøgersen. H. C. (1984). Generation of $\beta$-globin by sequence-specific proteolysis of a hybrid protein produced in Escherichia coli. Nature (London), 309. 810-812.

Neu. H. C. \& Heppel, L. A. (1965). The release of enzymes from Escherichia coli by osmotic shock and during the formation of spheroblasts. J. Biol. Chem. 240 , 3685-3692.

Palm, W. (1970). On the isolation, characterisation and crystallisation of a human Bence-Jones protein of kappa-type. FEBS Letters, 10, 46-48.

Palm, W. \& Hilschmann, N. (1973). Die Primärstruktur einer kristallinen monoklonalen Immungslobulin-L. Kette vom $\kappa$-Typ, Subgruppe I (Bence--Jones-Protein Rei.) ein Beitrag zur Aufklärung der dreidimensionalen Struktur der Immunglobuline. Hoppe-Seyler's Z. Physiol. Chem. 354, 1651-1654.

Pohlner, J., Halter, R., Beyreuther, K. \& Meyer, T. F. (1987). Gene structure and extracellular secretion of Neisseria gonorrhoeae IgA protease. Nature (London), 325, 458-462.

Riechmann, L., Foote, J. \& Winter, (. (1988). Expression of an antibody $\mathrm{F}_{\mathrm{v}}$ fragment in myeloma cells. $J . \mathrm{Mol}$. Biol. 203, 825-828.

Roberts, S., Cheetham, J. C. \& Rees. A. R. (1987). Generation of an antibody with enhanced affinity and specificity for its antigen by protein engineering. Nature (London), 328, 731-734

Sarthy, A., Michaelis, S. \& Beckwith, J. (1981). Deletion map of the Escherichia coli structure gene for alkaline phosphatase, phoA. J. Bacteriol. 145, 288-292.

Skerra, A. \& Plückthun, A. (1988). Assembly of a functional immunoglobulin $\mathrm{F}_{\mathrm{v}}$ fragment in Escherichia coli. Science, 240, 1038-1041.

Skerra, A., Pfitzinger, I. \& Plückthun, A. (1991). The functional expression of antibody $\mathrm{F}_{\mathrm{v}}$ fragments in Escherichia coli: Improved vectors and a generally applicable purification technique. Biotechnology, $\mathbf{9}$. 273-278.

Stanssens, P., Opsomer, C., McKeown Y. M., Kramer, W. Zabeau, M. \& Fritz. H.-J. (1989). Efficient oligonucleotide-directed construction of mutations in expression vectors by the gapped duplex DNA method using alternating selectable markers. Nucl. Acids Res. 17, 4441-4454.

Studier, F. W. \& Moffat, B. A. (1986). Lse of bacteriophage T7 RNA polymerase to direct selective highlevel expression of cloned genes. I. Mol. Biol. 189 $113-130$.

Sutcliffe, J. G. (1978). Nucleotide sequence of the ampicillin resistance gene of Escherichia coli pBR322. Proc. Nat. Acad. Sci., U.S.A. 75, 3737-3741.

Ward, E. S., Güssow, D., Griffiths, A. D., Jones, P. T. \& Winter, G. (1989). Binding activities of a repertoire of single immunoglobulin variable domains secreted from Escherichia coli. Nature (London), 341, $544-546$.

Waxman, L. \& Goldberg, A. L. (1982). Protease La from Escherichia coli hydrolyzes ATP and proteins in a linked fashion. Proc. Nat. Acad. Sci.. I.S.A. 79 4883-4887.

Wetzel, R. (1988). Active immunoglobulin fragments synthesized in $E$.coli-from Fab to scantibodies. Protein Eng. 2, 169-176.

Winter, G. \& Milstein, C. (1991). Man-made antibodies. Nature (London), 243, 293-299. 